\title{
Investigation of superior vena caval obstruction
}

\author{
A ALLAN, B SETHIA, KG DAVIDSON \\ From the Department of Cardiothoracic Surgery, Glasgow Royal Infurmary, Glasgow
}

Superior vena caval obstruction is a well recognised syndrome caused by compression of the great veins in the superior mediastinum. Although several conditions may produce this syndrome, most cases are caused by malignant neoplasms. In 3-20\% of cases, however, the cause may be benign $^{12}$ and it is therefore essential to establish a histological diagnosis before treatment. Procedures such as caval venography and computed tomography remain nonspecific, although they may show features suggestive of malignancy. ${ }^{3}$ Other procedures such as bronchoscopy and mediastinoscopy are frequently used to establish a diagnosis ${ }^{4}$ but some workers prefer to start radiotherapy without a tissue diagnosis ${ }^{5}$ on account of the reported dangers of bronchial biopsy in the presence of grossly raised venous pressures. ${ }^{6}$ Mediastinotomy and thoracotomy have also been advocated as alternative diagnostic procedures but they in turn predispose to operative haemorrhage in the presence of caval obstruction. To clarify our own diagnostic approach we reviewed our recent experience of the surgical investigation of superior vena caval obstruction.

\section{Methods and results}

From 1977 to 198317 patients (12 male), presented to the thoracic surgical unit at Glasgow Royal Infirmary with a diagnosis of superior vena caval obstruction. All patients had previously been assessed by non-invasive techniques and fibreoptic bronchoscopy had been performed in 11 cases. The patients were referred so that a positive histological diagnosis could be established.

Bronchoscopy, performed with general anaesthesia and a rigid endoscope, was carried out in 12 cases. Five of these patients had already undergone fibreoptic bronchoscopy. In two cases a positive tissue diagnosis was established. In one other patient a histological diagnosis was obtained after biopsy of a cervical lymph node at the time of bronchoscopy. In a further case the findings from lymph node biopsy were inconclusive and further investigation was abandoned because of the poor clinical state of the patient. Of the remaining 13 patients, 11 underwent mediastinoscopy. Malignant mediastinal nodes were identified and biopsy was performed uneventfully in nine cases. In two cases no abnormal tissue was identified. In only one case was any significant bleeding encountered and this was easily controlled by direct pressure without the need for blood transfusion.

The four patients in whom a diagnosis had not been

Address for reprint requests: Mr B Sethia, Department of Cardiac Surgery, Royal Infirmary Glasgow G31 2ER.

Accepted 10 July 1984 made by these methods were then investigated by mediastinotomy (three patients) or thoracotomy (one patient). In three patients (two of whom had previously undergone mediastinoscopy) a diagnosis of benign mediastinal fibrosis was established. The last patient was found to have lymphoma.

No significant morbidity and no deaths resulted from any of these procedures.

The investigations and results are summarised in the table. In 10 patients with superior vena caval obstruction (59\%) metastatic bronchogenic carcinoma was diagnosed. Lymphoma was identified in two patients $(12 \%)$ and one patient had a primary mediastinal tumour. Mediastinal fibrosis was diagnosed in a further three patients (18\%). A diagnosis was not established before mediastinal irradiation, in only one patient who was subsequently shown at necropsy to have metastatic small cell bronchial carcinoma.

\section{Discussion}

The range of diagnoses seen in our patients with superior vena caval obstruction is similar to that reported in other series and, as expected, metastatic bronchogenic carcinoma was the most common cause. Eighteen per cent of our patients, however, had benign disease, which was only diagnosed by mediastinotomy or thoracotomy. This is similar to the findings in the collected review of Banker $e^{t} a^{1}$ and re-emphasises the need for an adequate histological diagnosis in patients with superior vena caval obstruction before the start of treatment with radiotherapy or chemotherapy.

Computed tomography has been used to demonstrate gland masses in the mediastinum and can be useful in planning the surgical approach. Mediastinal computed tomography scans, however, may be difficult to interpret in this condition as it is often difficult to separate lymph nodes from dilated veins, although contrast enhancement may help.

Although caval venography, as advocated by some authors, ${ }^{3}$ may suggest the presence of malignancy, we believe that this technique is of most value when palliative venous bypass is contemplated.

Despite previous reports suggesting that bronchoscopy and mediastinoscopy may be dangerous in the presence of superior vena caval obstruction, we encountered no appreciable problems. We have a policy when obtaining biopsy samples of lesions at bronchoscopy or mediastinoscopy of avoiding random tissue sampling and focusing our attention on areas of bronchial mucosa or mediastinal tissue which clearly appear abnormal on direct vision. With such precautions and care during the procedure it is possible to avoid excessive haemorrhage. Any distended veins 
Investigations and results in patients with superior vena caval obstruction

\begin{tabular}{|c|c|c|c|c|c|c|}
\hline Patient & Age & Sex & Bronchoscopy & Mediastinoscopy & Other procedure & Histological diagnosis \\
\hline $\begin{array}{r}1 \\
2 \\
3 \\
4 \\
5 \\
6 \\
7 \\
8 \\
9 \\
10\end{array}$ & $\begin{array}{l}60 \\
73 \\
31 \\
53 \\
62 \\
59 \\
62 \\
73 \\
66 \\
61\end{array}$ & $\begin{array}{l}\mathbf{F} \\
\mathbf{M} \\
\mathbf{M} \\
\mathbf{F} \\
\mathbf{M} \\
\mathbf{M} \\
\mathbf{M} \\
\mathbf{M} \\
\mathbf{M} \\
\mathbf{M}\end{array}$ & $\begin{array}{l}- \\
\overline{-} \\
\overline{-} \\
\overline{-} \\
\overline{+} \\
+ \\
+\end{array}$ & $\begin{array}{l}+ \\
+ \\
+ \\
+ \\
+ \\
+\end{array}$ & + & $\begin{array}{l}\text { Carcinoma of bronchus: } \\
\text { Small cell } \\
\text { Small cell } \\
\text { Small cell } \\
\text { Squamous } \\
\text { Squamous } \\
\text { Squamous } \\
\text { Large cell } \\
\text { Large cell } \\
\text { Large cell } \\
\text { Adenocarcinoma }\end{array}$ \\
\hline $\begin{array}{l}11 \\
12 \\
13 \\
14 \\
15 \\
16 \\
17\end{array}$ & $\begin{array}{l}52 \\
60 \\
40 \\
51 \\
31 \\
33 \\
56\end{array}$ & $\begin{array}{l}\mathbf{M} \\
\mathbf{M} \\
\mathbf{F} \\
\mathbf{F} \\
\mathbf{M} \\
\mathbf{M} \\
\mathbf{F}\end{array}$ & $\begin{array}{l}- \\
\overline{-} \\
\overline{-} \\
\overline{-} \\
\overline{-}\end{array}$ & $\begin{array}{l}+ \\
+ \\
- \\
-\end{array}$ & $\begin{array}{l}+ \\
+ \\
+ \\
+ \\
+\end{array}$ & $\begin{array}{l}\text { Primary mediastinal tumour } \\
\text { Lymphoma } \\
\text { Lymphoma } \\
\text { Mediastinal fibrosis } \\
\text { Mediastinal fibrosis } \\
\text { Mediastinal fibrosis } \\
\text { No diagnosis }\end{array}$ \\
\hline
\end{tabular}

+ indicates positive diagnosis achieved and - not diagnostic.

may be retracted laterally at mediastinoscopy to improve the view of the mediastinum. ${ }^{4}$ Mediastinoscopy has resulted in a high diagnostic yield $(82 \%)$ and no attendant morbidity. This experience refutes the suggestion that mediastinoscopy is contraindicated in superior vena caval obstruction. The technique is relatively simple when carefully performed and is less traumatic than formal thoracotomy in debilitated patients. Furthermore, wound healing need not delay further treatment.

Mediastinotomy has been advocated as a safe alternative to mediastinoscopy. In our experience this has been a useful investigation when larger tissue samples are required for histological diagnosis. It is, however, a more traumatic investigation for the patient and should therefore be used only in patients in whom mediastinoscopy has failed to establish a tissue diagnosis. The investigations of bronchoscopy, mediastinoscopy, and mediastinotomy can all be performed safely in patients with superior vena caval obs- truction. A positive histological diagnosis can be obtained in most patients, thereby facilitating the management of this distressing condition.

\section{References}

' Banker VP, Madson FS. Superior vena caval syndrome secondary to aortic disease: report of two cases and a review of the literature. Dis Chest 1967;51:656-62.

${ }^{2}$ Mahajan V, Strimlan V, Van Ordstend H, Loop FD. Benign superior vena caval syndrome. Chest $1975 ; 68: 32-5$.

${ }^{3}$ Lockridge S, Knibble, WP, Doty DB. Obstruction of the superior vena cava. Surgery 1979;85:14-24.

4 Nohl-Oser HC. Mediastinoscopy. Br J Hosp Med 1976;16:33-6.

${ }^{5}$ Lokich JJ, Goodman R. Superior vena cava syndrome clinical management. JAMA 1975;231:58-61.

- Boruchow IB, Johnson J. Obstructions of the vena cava. Surg Gynecol Obstet 1972;134:115-21. 